\title{
THE RELATIONSHIP BETWEEN GRAPE AND FRUIT PRODUCTION IN EGER AND ITS SURROUNDINGS
}

\author{
Anita Berecz
}

\begin{abstract}
In my paper, I focus on what role fruit production played in Eger, which tree species were preferred, and how the phylloxera plague in the 1880s contributed to making vegetable and fruit production an important branch of agriculture in the hóstyas (outer districts) of Eger. The relevant, primarily ethnographic data-collection highlights that research into independent folk fruit production started only late and only in some areas. By combining these data, we can still gather much information on issues about fruit production from the studies dealing with farming. The agricultural journals of Eger launched from the second third of the 19th century provide further analysis of the fruit production in Eger.
\end{abstract}

Keywords: the wine region of Eger, fruit production, tree species, phylloxera plague CODE: B19 


\section{Introduction}

In the report describing the inhabitants of Eger, a 19th-century geographer and statistician, Elek Fényes wrote in his work published in 1837 that "they live mainly from wine growing, crafts and trades." (Fényes, 1837) This statement is confirmed in his geographical dictionary of 1851: "Their main occupation is growing grapes, then the conduct of crafts and trades. The vineyard of Eger is such a vast area, produces such a famous red wine that nobody surpasses in goodness and flavour in Hungary. The best, noblest wine is produced on its high mountain of Egyed, but 4-5 years are needed for perfect development, although the one grown on Síkhegy and Tihamér grows ripe in a year. All kinds of domesticated winter and summer fruit are grown in the gardens and at the bottom of the mountains in great abundance; and on the hill of Egyed, sumac or poison ivy, which can be used well in leather factories."(Fényes, 1851) In his work published in 1853, Károly Mártonffy, a prominent figure in the viticulture of Eger, wrote about the importance of the role viticulture plays in the economic life of the city as follows: "Wine production is the major economic force of Eger. The majority of its inhabitants, the hoers live on the daily rates earned purely from wine production; there are hardly any decent citizens in Eger who would not grow grapes besides their profession or craft." (Mártonffy, 1853)

\section{Sources}

I paid particular attention to the literature and censuses related to fruit production in the 19th century, which takes into account the phenomena concerned with the situation of the surrounding area and that of fruit production in a general sense. The relevant, primarily ethnographic data-collection highlights that research into independent folk fruit production started only late and only in some areas. By combining these data, we can still gather much information on issues about fruit production from the studies dealing with farming. The agricultural journals of Eger launched from the second third of the 19th century provide further analysis of the fruit production in Eger.

\section{Results}

Thus, according to contemporary descriptions, the importance of viticulture stands out in the life of the city, and despite the fact that it was dominated by wine growing in the whole county, fruit production also gained greater impetus and developed gradually from the second half of the 18th century, as is clear from Elek Fényes' 
description. This is shown by the fact that the Economic Journals published in 1854 had already dealt with the horticulture of Eger in detail, including the cultivation of the pear of Eger. Concerning the pears of Eger, they pointed out that they had a beautiful and natural pyramid shape and ripen late, so they do not offer opportunities for stealing. On the other hand, they drew attention to the fact that the soil which they are planted into should not be waterlogged, as the pear trees of Eger and pear trees in general do not tolerate it well. (Economic Journals, 1854, Vol. 6, No. 1-5)

Among other things, the phylloxera plague of the 1880s contributed greatly to the fact that growing fruit and vegetables became an important branch of agriculture in the hóstyas (outer districts). (Guszmanné, 2007) The soil along the stream of Eger, the floodplain of which provided loose, abundant soil, provided excellent conditions for vegetable production in Eger, becoming famous by the end of the 19th century. Vegetable and fruit production was an important source of income for the population of the hóstyas i.e. the outer districts of Eger. The inhabitants of Eger supplied the whole Northern Hungary with the vegetables grown in Kertész street, - still known as Zellervár -, inhabited by mainly German gardeners. Thus, the population of the Maklár hóstya profited greatly from the vegetable production evolved during the1819th century, where there was significant vegetable production even in the middle of the 20th century (Farkasvölgy, Lajosváros, Kanada). The good location and soil were extremely suitable for the production of various fruit species. Frequently, farmers also grew and cultivated several fruit trees even in the vineyards themselves; they preferred especially stone fruits. Thus, most winegrowers had smaller or larger orchards, or at least fruit trees, scattered in or around the vineyard. "Along with wine cultivation, we can find fruit production everywhere; fruit trees, however, are still grown under unfavourable conditions in many places even today," said Samu Borovszky, a monographer presenting the county of the time, reporting on the conditions at the turn of the century. (Borovszky, 1909) The Highlands had been the only market for certain fruit species of Heves County for centuries, supplying its markets with cherries and summer and autumn's peaches. As traffic conditions improved, demand also picked up, resulting in the development of fruit production and the appreciation of fruit trees. A report from the second half of the 19th century also confirms the importance of fruit production: "Cherries, apples, pears and summer and autumn's peaches are grown in such large quantities and of such good quality in the outskirts of Eger that they are taken to the Great Plain and exchanged for wheat by the women of Eger. " (Albert, 1868) The main fruits of mountain regions were cherries, nuts, plums, sour cherries, autumn and summer peaches to a small extent, while those of the plains were apples, pears, plums, summer and peaches, cherries, sour cherries and nuts. Cherries were the most widespread and most valuable fruit species in Eger and its surroundings, because they had high yields every year. Of these, the "the First Grapes of the Season of Eger" played a major role, which were was red, sweet enough and had a pleasant taste at the 
end of May; in addition, the large, black, crunchy and pink "blistered" cherries were popular. Of the nuts the common and soft shell varieties; of the plums the "Beszterce" ones and the various varieties of greengages; of the sour cherries the "Spanish" ones and the "Nagy-Körös" ones, and the small, so called "gypsy sour cherries" were widespread. Of the summer's peaches the "Hungarian best", of the autumn's peach species the early "Sándor" and the late "Duránci" varieties were popular. Of the apples the "golden parmen", "skin apple", "lemon apple", "Kalvil", "Bálint Török" varieties, while of the pears the "emperor", the "butter" pears, the yellow and green "purgament" varieties and the "Eger" pear were popular. The developed fruit culture of the Eger and Gyöngyös regions also laid the foundation for the widespread production of spirits. In 1890, the Chamber of Commerce and Industry of Miskolc mentioned Ferenc Preszler's distillery in Eger as a large industrial distillery. (Kriston, 1992)

In the 1920s, a special article in the Magazine of Horticulture dealt with the fact that during the ripening of cherries, 6-8 wagons of Eger black cherries were delivered to the Vienna market daily. This variety was so popular with the Vienna market that it did not accept any other variety. As a result, the growers in Eger did not take great pains to find other cherry varieties. Of course, there were other cherry varieties of good quality that also sold well. In addition, there was a widespread view that if cherries were taken good care of in a region, they would grow to a large size. (Magazine of Horticulture, 1926, No. 106) In the 1930s, the Magazine of Cities reported as special news that pilot vineyards and orchards would be established in the outskirts of Eger. An Economic Committee was established under the leadership of the social associations and representatives of Eger to organize the production in Eger, and to facilitate the sale of grapes, fruits, vegetables and other crops. The Commission wanted to provide not only advice and guidance on production and sales issues to the general public, but also practical solutions that would soon have an impact on economic life of Eger. (Magazine of Cities, 1937, Vol. 6.)

\section{Conclusions}

The main objective of agricultural history research is to study which tree species were preferred and how contributed the relationship between grape and fruit production in Eger and its surroundings. To sum up these things, the vineyard of Eger and its produces such a famous red wine has become modern, famous area and vine from the beginning of $19^{\text {th }}$ century in Hungary. The best wine is produced on its high mountain of Egyed, but 4-5 years are needed for perfect development, although the one grown on Síkhegy and Tihamér grows ripe in a year. All kinds of domesticated winter and summer fruit are grown in the gardens and at the bottom of the mountains in great abundance; and on the hill of Egyed. 


\section{Reference sources}

[1.] Fényes Elek (1837): Magyarországnak, s a hozzá kapcsolt tartományoknak mostani állapotja statisztikai és geographiai tekintetben. [The current state of Hungary and its annexed provinces in terms of statistics and geography]. III., Pest.

[2.] Fényes Elek (1851): Magyarország geographiai szótára. [Geographical dictionary of Hungary]. I, Pest.

[3.] Mártonffy Károly (1853): Eger szőllőgazdászata munkája Magyarország és Erdély képekben, [The vinticulture of Eger, Hungary and Transylvania in Pictures]. Kubinyi Ferenc és Vahot Imre IV., Pest.

[4.] Gazdasági Lapok. [Magazine of Economics], 1854. 6. évfolyam, 1-5. szám.

[5.] Guszmanné Nagy Ágnes - Miskolczi László - Petercsák Tivadar (szerk.) (2007): Az egri hóstyák. [The hóstyas (regional districts) of Eger], Eger, Varga Nyomda Kft. 61-74.

[6.] Borovszky Samu (szerk.) (1909): Magyarország vármegyéi és városai. Heves vármegye. [Counties and cities in Hungary. Heves County]. Budapest.

[7.] Albert Ferenc (1868): Heves és Külső Szolnok törvényesen egyesült vármegyéknek leírása. [Description of the legally united Heves County and Outer Szolnok County]. Eger. 79-80.

[8.] Kriston Pál (1992): Heves megye iparosítása a dualizmus korában. [Industrialization of Heves County in the Age of Dualism]. Studia Agriensia 13. Eger. 55.

[9.] Kertészeti Lapok. [Magazine of Horticulture]. 1926. 10. szám.

[10.] Városok Lapja. [Magazine of Cities] 1937. 6. szám

\section{Szerző}

\section{Anita Berecz}

Assistant research fellow Eszterházy Károly University

Department of History berecz.anita@uni-eszterhazy.hu 